
Manan

\title{
Self-Fibers Compacting Concrete Properties Reinforced with Propylene Fibers
}

https://doi.org/10.1515/secm-2021-0006

Received Aug 04, 2020; accepted Dec 11, 2020

\begin{abstract}
Self-Consolidating Concrete (SCC) has also brittle characteristics. This is unacceptable for any construction industry. The addition of fibers is one of the most common methods to enhance the tensile strength of concrete. Fiber controls the cracking phenomena and enhances the energy absorption capability of the concrete. On the other hand, the addition of fibers has a negative impact on the workability of fresh concrete. In this paper, a detailed study on the influence of Propylene fibers (PP) on the fresh properties of SCC was carried out. PFs were added into concrete mixes in a proportion of $1.0 \%, 2.0 \%, 3.0 \%$, and $4.0 \%$ by weight of cement to offset its undesirable brittle nature and enhance its tensile strength. The fresh characteristics were evaluated based on its passing ability, flowability using, Slump flow, Slump T50 Spread time, L-Box and V-funnel tests as well as mechanical performance (compressive and split tensile strength) were also evaluated at 7,14 and 28 days curing. Test results indicate that the passing and filling ability decreased as the substitution ratio of PP increased. Besides, the test result indicates that strength was increased up to $2.0 \%$ addition of PP and then decrease gradually.
\end{abstract}

Keywords: Fibers, Compressive strength, self-consolidating concrete, flowing passing, and filling ability

\footnotetext{
*Corresponding Author: Jawad Ahmad: Department of Civil
Engineering, Swedish College of Engineering and Technology, Wah

^Corresponding Author: Jawad Ahmad: Department of Civil
Engineering, Swedish College of Engineering and Technology, Wah Cantt, 47040, Pakistan; Email: jawadcivil13@scetwah.edu.pk Fahid Aslam, Rayed Alyousef, Hisham Alabduljabbar: Department of Civil Engineering, College of Engineering in Al-Kharj, Prince Sattam Bin Abdulaziz University, Al-Kharj 11942, Saudi Arabia Osama Zaid: Department of Civil Engineering, Swedish College of Engineering and Technology, Wah Cantt, 47040, Pakistan Aneel Manan: School of International Education, Department of Civil Engineering, Zhengzhou University, 101 Science Avenue, Zhengzhou, China
}

2 Open Access. () 2021 J. Ahmad et al., published by De Gruyter. (cc) BY License

\section{Introduction}

Self-Consolidating Concrete (SCC) is a special concrete that is highly flowable, non-segregating and by its weight spread into place, fills the formwork even in the presence of dense reinforcement [1]. The concept of self-compacting concrete (SCC) was developed in 1986 by Hajime Okamura [2], however, the prototype was proposed in Japan in 1988 by Ozawa [3].

In construction industries, concrete is the highest used material for its high compressive strength. But concrete has a very low tensile capacity which results in abrupt failure in the concrete structure. Different types of fibers are used in concrete to increase the tensile capacity of concrete under tension loading. The Majority of Steel fiber reinforced concrete has the capability of brilliant shock resistance, ductility, flexural strength, tensile strength, Crack arrest \& fatigue resistance. "In 1910, Porter first recommended the use of steel fibers in concrete [4]. The first research on reinforced fiber concrete in the US was performed in 1963 [5]. Research shows that as compare to thick fibers, thin fibers are more effective in reducing the width of plastic shrinkage cracks as reported in ACI 544.5R-10 [6]. The positive significance of steel fibers in concrete depends on many factors such as shape, length, type, strength cross-section, mix design, matrix strength fiber content, \& steel fiber bond strength [7]. Between these high-performing concretes, for the benefits of economical cost, easy fabrication, performance improvements, steel fiber-reinforced concrete is used extensively for engineering purposes [8,9]. However, a general observation showed that uneven addition of steel fiber would affect the fluidity and uniformity of concrete mixing and even results in poor fiber bonding, which eventually affects the reinforcement effect of mechanical properties [10-12].

Some studies show that self-fiber compacting concrete composites under impact were able to dissipate much more energy as compared to conventional concrete reinforced with polymeric or steel fiber [13]. The research was carried out on mechanical properties of the macro polypropylene (PP) fiber-reinforced concrete, including the flexural and tensile strengths, fracture toughness, and fracture en- 
ergy [14]. Studies were performed using waste carpet fibers in concrete as an environmentally friendly use of recycled carpet waste [15].

Despite that, there are various benefits from using different types of fibers in concrete, it is well known that any type of fiber will reduce the workability [16, 17]. Fibers have a relatively large surface area which increased the water demand. At the same time, more potential energy is needed for fresh concrete to flow by its weight due to increase friction between aggregate and fibers in the mixes [18]. Most of the studies present in the literature focus only on the hardened properties of fibers reinforced concrete [19-25]. Very few studies focus on the workability of fibers reinforced concrete [36]. The major difference between conventional concrete and SSC is fresh characteristics. The fresh characteristics were evaluated based on its passing ability, flowability, bleeding and segregation resistance using, Slump flow, Slump T50 Spread time, L-Box, V-funnel, and sieve segregation tests as well as mechanical properties (compressive and split tensile strength) were also evaluated. Test results indicate that the filling and passing ability decreased while bleeding and segregation resistance increased with PP. Besides, the test result indicates that strength was increased up to $2.0 \%$ addition of PP fiber and then decrease gradually.

\section{Experimental Program}

\subsection{Materials}

\subsubsection{Cement}

Ordinary Portland cement (OPC) type-1 in accordance with American Standard of Testing Materials ASTM C150 [28] was used in the making of concrete mixes. Its chemical and physical properties are displayed in Table 1.

\subsubsection{Propylene fibers (PP)}

Propylene fibers used in this study were $35 \mathrm{~mm}$ long with a diameter of $0.55 \mathrm{~mm}$. Its properties are given in Table 2.

Table 2: Physical Property of Propylene Fibers

\begin{tabular}{cc}
\hline Physical Property & Results \\
\hline Length & $35 \mathrm{~mm}$ \\
Diameter & $0.55 \mathrm{~mm}$ \\
Aspect ratio (L/d) & 64 \\
Tensile Strength & $1345 \mathrm{Mpa}$ \\
Young's & \\
Modulus & $200 \mathrm{GPa}$ \\
\hline
\end{tabular}

\subsubsection{Fine and Coarse Aggregate}

Natural river sand was used as a FA (fine aggregate) in all the mixes in SSD (saturated surface dry) condition which was obtained from local market Risalpur Pakistan. Normal weight coarse aggregate (crush stone) with a nominal maximum size $19.5 \mathrm{~mm}$ was used as aggregate in all the mixes in SSD (saturated surface dry) condition which was obtained from local market Risalpur Pakistan. Different tests were conducted to evaluates its physical properties. Physical properties of fine and coarse aggregate were given in Table 3.

Table 1: Physical and Chemical Property of OPC

\begin{tabular}{cccc}
\hline Chemical Property & Percentage (\%) & Physical Property & Results \\
\hline $\mathrm{CaO}$ & 63.7 & Size & $\leq 75 \mu$ \\
$\mathrm{SiO}_{2}$ & 24.9 & Fineness & $91 \%$ \\
$\mathrm{Al}_{2} \mathrm{O}_{3}$ & 6.4 & Normal & $29 \%$ \\
& & Consistency & \\
$\mathrm{Fe}_{2} \mathrm{O}_{3}$ & 3.7 & Initial & $33 \mathrm{~min}$ \\
& & Stetting Time & \\
$\mathrm{MgO}$ & 4.5 & Final & $411 \mathrm{~min}$ \\
& & Stetting Time & \\
$\mathrm{SO}_{3}$ & 0.9 & Specific surface & $322 \mathrm{~m}^{2} / \mathrm{kg}$ \\
$\mathrm{K}_{2} \mathrm{O}$ & 1.4 & Soundness & $0.60 \%$ \\
$\mathrm{Na}_{2} \mathrm{O}$ & 1.2 & 28-days compressive Strength & $42 \mathrm{Mpa}$ \\
\hline
\end{tabular}


Table 3: Physical Property of Fine and Coarse Aggregate

\begin{tabular}{ccc}
\hline Physical Property & $\begin{array}{c}\text { Fine } \\
\text { aggregate }\end{array}$ & $\begin{array}{c}\text { Coarse } \\
\text { Aggregate }\end{array}$ \\
\hline Particle Size & $4.75 \mathrm{~mm}$ to & $25 \mathrm{~mm}$ to \\
& $0.075 \mathrm{~mm}$ & 4.75 \\
Fineness Modulus & 2.73 & 5.7 \\
Absorption Capacity & $4.28 \%$ & $2.18 \%$ \\
Moisture Content & $2.8 \%$ & $0.45 \%$ \\
Bulk density & 1626 & 1560 \\
\hline
\end{tabular}

\subsubsection{Superplasticizer}

Chemrite-530 is used as a superplasticizer because it is high range water reducing admixture and non-toxic and non-hazardous under relevant health and safety issues. Chemrite-530 is a very capable superplasticizer with a set retarding effect for the production of free-flowing concrete in hot weather. The superplasticizer meets the requirements of EN 934-2 T 3.1/3 [29]. and ASTM C-494 Type F [30]. Typical properties of the superplasticizer are given in Table 4.

Table 4: Physical Property of Superplasticizer

\begin{tabular}{cc}
\hline Property & Result \\
\hline Color & Brown \\
Relative density & 1.48 at $25^{\circ} \mathrm{C}$ \\
Chloride content & $<0.1 \%$ \\
Physical state & Liquid \\
\hline
\end{tabular}

\subsubsection{Experimental program}

To obtain the goal of the project, A two-stage experimental program was developed. In the first stage, a trial mix was made to achieve the requirement of technical specification for SCC [1]. In the second stage of experimental work, six mixes were prepared with varying percentages of $\mathrm{PP}(0 \%$, $1.0 \% .2 .0 \% .3 .0 \%, 4.0 \%$ ) to determine the effects of PP on self-compacting concrete (SCC), which are based on the finding of the first stage. Typical acceptance criteria for Selfcompacting Concrete define by the technical specification for self-compacting concrete with maximum aggregate size up to $20 \mathrm{~mm}$ are shown in Table 5.
Table 5: Typical Acceptance Criteria for Self-Compacting Concrete

\begin{tabular}{ccccc}
\hline Sr.NO & $\begin{array}{c}\text { Tests } \\
\text { Methods }\end{array}$ & Unit & Minimum & Maximum \\
\hline 1 & Slump Test & Mm & 650 & 800 \\
2 & T50-Slump & Sec & 2 & 5 \\
& Flow & & & \\
3 & L-Box Test & $(\mathrm{H} 2 / \mathrm{H} 1)$ & 0.8 & 1 \\
4 & V-Funnel & Sec & 6 & 12 \\
& Tests & & & \\
\hline
\end{tabular}

\subsubsection{Tests and Size of Specimen}

Fresh properties of SCC such as Slump flow, Slump T50 Spread time, L-Box, V-funnel will be performed according to technical specification for SCC [1]. ASTM C39/C39M [31] Cylinder of standard size (6x12in) will be used to measure the compressive strength at 7,14 \& 28 days. Similar cylinders of standard size ( $12 \times 18 \mathrm{in})$ will be cast \& tested to find their tensile strength as per ASTM standard [32]. Three specimens are tested for each test at 7,14 and 28 days and the mean value of the specimens is considered as strength.

\subsubsection{Sample Preparation Method}

ASTM C-31 [33] method was followed for the preparation of the specimens and compaction was done manually by Roding in three layers having 25 blows per layer. Six mixes are prepared with the varying dosage of PP $0 \%, 1.0 \% .2 .0 \%$. $3.0 \%, 4.0 \%$ by weight of cement. Details of the trial mixes are provided in the following Table 8. Before the mixing process was started, the required quantity of material was weighed by the method of weighing. Speed of mixer was kept $35 \mathrm{rev} / \mathrm{min}$ for mixing of materials. First, the coarse aggregate was added to the mixer and then fine aggregate, both materials were dry mixed then the necessary quantity of cement and water were added with time and mixing was done about 8 minutes for all mixes. The details of each trial's mixes were shown in Table 6 .

\section{Test Results}

\subsection{First Stage Results}

In the first stage, eight mixes as shown in Table 6 were prepared to achieve the best possible mix which would fulfill the requirement of Technical Specification for (SCC). Based on work results, fresh properties of SCC for each trial 
Table 6: Trials Mixes for Self-Compacting Concrete (SCC)

\begin{tabular}{ccccccccc}
\hline Materials & Mix 1 & Mix 2 & Mix 3 & Mix 4 & Mix 5 & Mix 6 & Mix 7 & Mix 8 \\
\hline Cement $\left(\mathrm{kg} / \mathrm{m}^{3}\right)$ & 425 & 425 & 425 & 425 & 425 & 425 & 425 & 425 \\
Sand $\left(\mathrm{kg} / \mathrm{m}^{3}\right)$ & 625 & 625 & 625 & 625 & 625 & 625 & 625 & 625 \\
Crush $\left(\mathrm{kg} / \mathrm{m}^{3}\right)$ & 1270 & 1270 & 1270 & 1270 & 1270 & 1270 & 1270 & 1270 \\
W/C & 0.50 & 0.50 & 0.50 & 0.50 & 0.60 & 0.60 & 0.60 & 0.60 \\
Superplasticizer $(\mathrm{kg})$ & - & 2.12 & 4.25 & 6.37 & - & 2.12 & 4.25 & 6.37 \\
\hline
\end{tabular}

Table 7: Results of Trial Mixes for Self-Compacting Concrete (SCC)

\begin{tabular}{|c|c|c|c|c|c|c|c|c|}
\hline Tests Methods & Mix 1 & $\operatorname{Mix} 2$ & Mix 3 & Mix 4 & Mix 5 & Mix 6 & $\operatorname{Mix} 7$ & Mix 8 \\
\hline Slump (mm) & 515 & 532 & 558 & 632 & 592 & 785 & 830 & 868 \\
\hline $\begin{array}{l}\text { L-Box Test } \\
\text { (H2/H1) }\end{array}$ & 0.58 & 0.64 & 0.71 & 0.85 & 0.74 & 0.94 & 0.92 & 0.97 \\
\hline $\begin{array}{l}\text { V-Funnel Tests } \\
(\mathrm{Sec})\end{array}$ & 19 & 16 & 15 & 11 & 15 & 7 & 5 & 2.8 \\
\hline T50-Slump Flow & 11 & 9 & 7 & 5.2 & 6 & 4.7 & 2.8 & 2.1 \\
\hline $\begin{array}{c}\text { Remarks As per } \\
\text { EFNARC }\end{array}$ & $\begin{array}{l}\text { Too Stiff } \mathrm{f}_{+} \\
\text {Segregation }\end{array}$ & $\begin{array}{l}\text { Too } \\
\text { Stiff }\end{array}$ & $\begin{array}{l}\text { Small } \\
\text { Stiff }\end{array}$ & $\begin{array}{c}\text { Small } \\
\text { Bleeding }\end{array}$ & $\begin{array}{c}\text { Small } \\
\text { Stiff }\end{array}$ & $\begin{array}{l}\text { Good } \\
\text { SCC }\end{array}$ & $\begin{array}{c}\text { Small } \\
\text { Bleeding }\end{array}$ & $\begin{array}{l}\text { Too Bleeding + } \\
\text { Segregation }\end{array}$ \\
\hline
\end{tabular}

Table 8: Mix Proportion of SCC

\begin{tabular}{cccccc}
\hline Materials & PP-0\% & PP-1.0\% & PP-2.0\% & PP-3.0\% & PP-4.0\% \\
\hline Cement $\left(\mathrm{kg} / \mathrm{m}^{3}\right)$ & 425 & 425 & 425 & 425 & 425 \\
Sand $/ \mathrm{F} . \mathrm{A}\left(\mathrm{kg} / \mathrm{m}^{3}\right)$ & 625 & 625 & 625 & 625 & 625 \\
Crush $/$ C.A $\left(\mathrm{kg} / \mathrm{m}^{3}\right)$ & 1270 & 1270 & 1270 & 1270 & 1270 \\
W/C & 0.60 & 0.60 & 0.60 & 0.60 & 0.60 \\
Superplasticizer $(\mathrm{kg})$ & 2.12 & 2.12 & 2.12 & 2.12 & 2.12 \\
PP $(\mathrm{kg})$ & - & 2.125 & 4.25 & 6.37 & 8.50 \\
\hline
\end{tabular}

mix with different test methods (Slump flow, Slump T50 Spreads, L- Box and V-funnel) were shown in Table 7. it is clear from Table 7 that, Mix 6 will satisfy the range of different test (Slump flow, Slump T50 Spread time, L-Box and V-funnel) given by specified by the technical specification for self-compacting concrete. While others mix does not satisfy the range of such tests. Therefore Mix 6 is considered the best mix of self-compacting concrete and can be used as a reference concrete (control) with varying percentages of PP.

\subsection{Second Stage (Mix Proportion of SCC)}

Based on the work results of the first stage, Mix 6 (SCC) was selected for further experimental work (control). Therefore, the second stage of the experimental work was conducted on Mix 6 (SCC) with the incorporation of PP. Five mixes were prepared at the second stage after achieved the requirement of technical specification for SCC (Mix 6) which given in the first stage as shown in Table 7. Different percentages of PP were added to fresh self-compacting concrete (SCC). The percentages of PP used were $0 \%, 1.0 \% .2 .0 \% .3 .0 \%$, $4.0 \%$ by weight of cement. Table 8 shows the concrete mix proportions of SCC.

\subsubsection{Rheological Properties}

\subsubsection{Slump Flow and Slump T50}

Slump and slump flow were obtained by a slump flow test. Results of Slump flow and Slump T50 test were shown in Figure 2 and Figure 3 respectively. The test results indicate that Slump flow decreased while Slump T50 value increased as the percentage of PP increased. The reduction of concrete mix workability when PPF is added is attributed to the surface area of PP which required more cement paste to coat them and hence less cement paste is past available for 


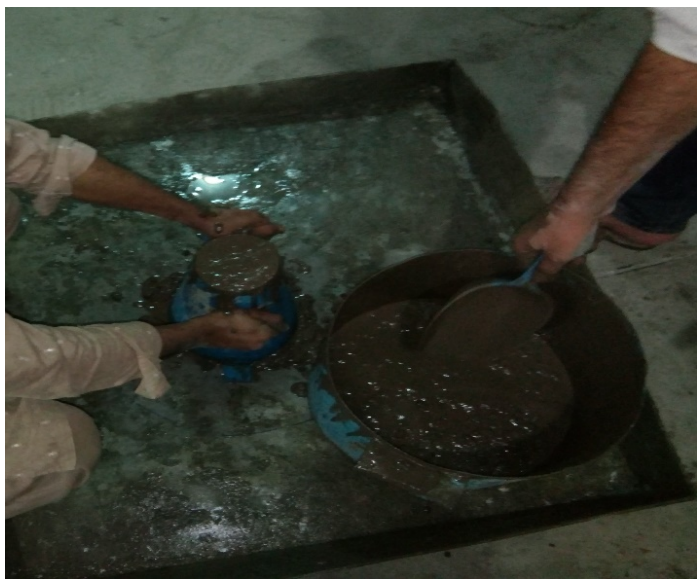

(a)

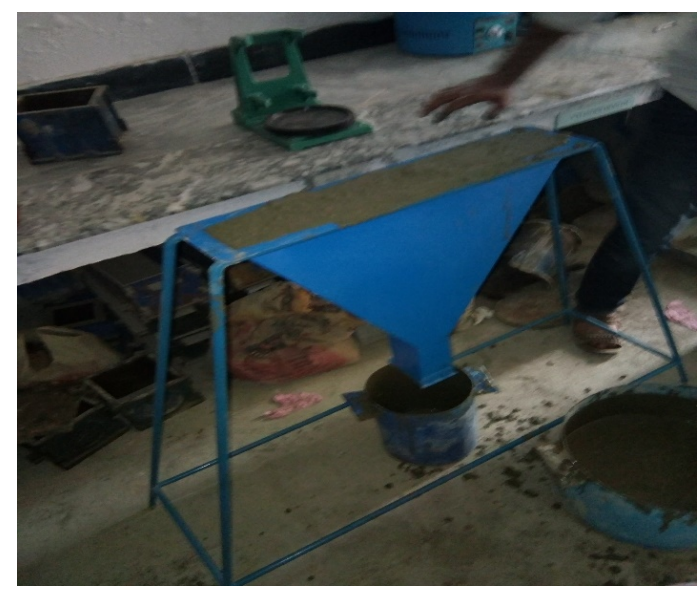

(c)

Figure 1: (a), (b) Slump Flow, (c) V-Funnel, (d) L-Box Tests

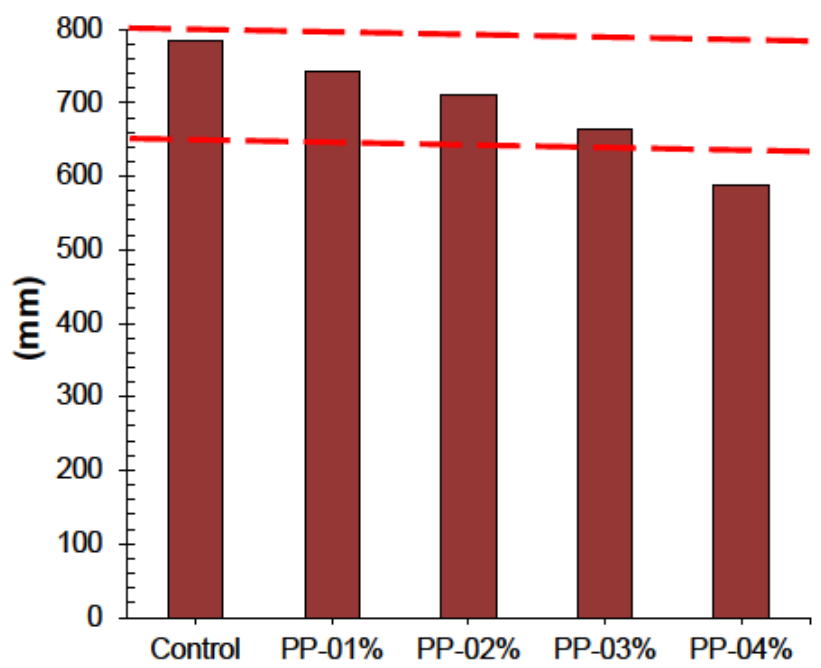

Figure 2: Slump Test Results

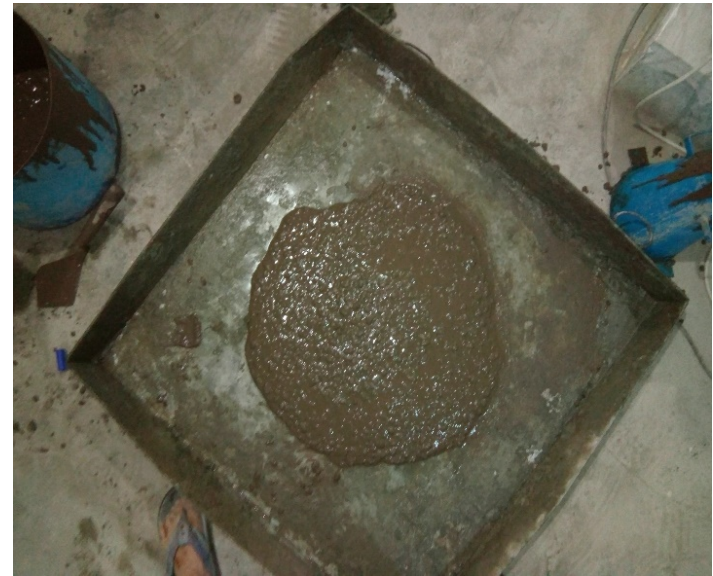

(b)

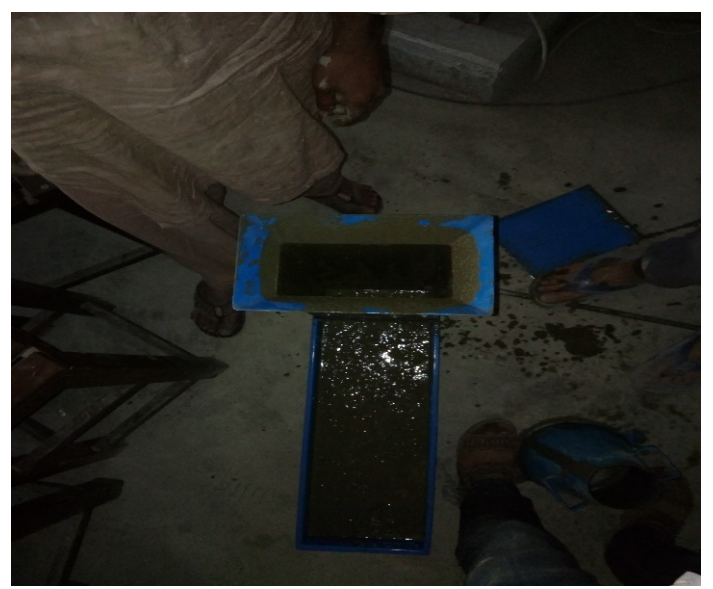

(d)

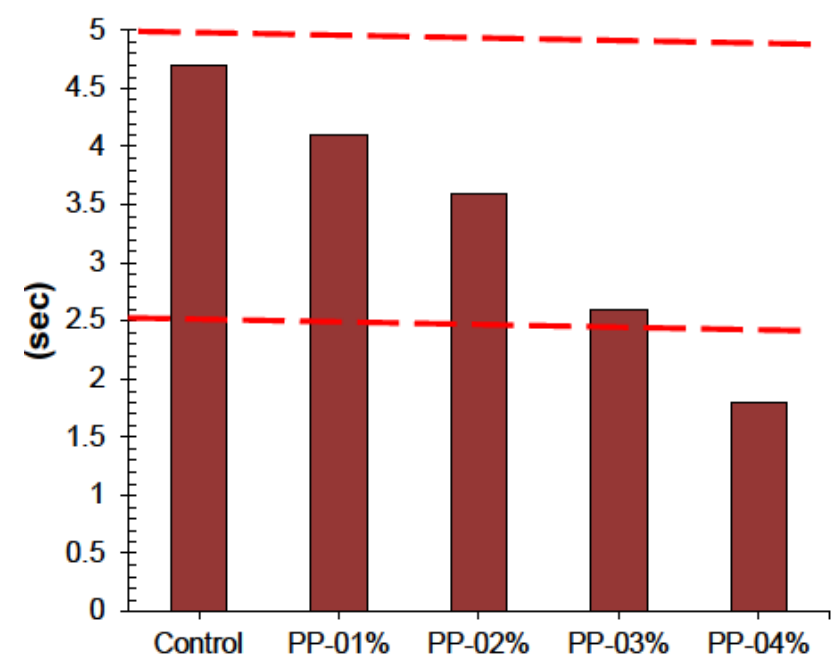

Figure 3: SlumpT50 Test Results 
lubricating. Also, PP increased the friction between aggregate and fibers which required more paste to reduce such friction. Based on work results, PP up to $3.0 \%$ addition, the Slump flow and Slump T50 value fall in acceptable range as defined by the technical specification for SCC and have the good filling ability. However, at a higher dosage of PP$4.0 \%$, have Slump flow and Slump T50 out of range given by technical specification for SCC. Therefore, a high dosage of superplasticizer is needed.

\subsubsection{L-Box Test and V- Funnel Test}

L-Box test was used to assess the passing ability of selfconsolidating concrete. Similar to slump flow, the passing ability of concrete decreased as the percentages of PPF increased. The typical acceptable range of blocking ratio for the good passing ability of SSC according to technical specification for SSC is 0.8 to 1.0.Mixes (PP-0\%, PP-1.0\%, PP$2.0 \%$ and $\mathrm{PP}-3.0 \%)$ have L-Box test ratio $(\mathrm{H} 2 / \mathrm{H} 1)$ value in between 0.80 to 1 except PP-2.0\%) as shown in Figure 4. which means, as these mixes (PP-0\%, PP-2.0\%, and PP$3.0 \%$ ) satisfied the requirement given by technical specification for SCC have a good filling and passing ability. While mix PP-4.0\%, have L-Box test ratio $\left(\mathrm{H}_{2} / \mathrm{H}_{1}\right) 0.73$, which is out of range given by technical specification for SCC as shown in Figure 4. However, it should be noted that [34] determined that a 0.60 blocking ratio has been accepted for SCC to achieved good filling ability. According to this standard, once the value of $h 2 / h 1$ in the $L$ box test is greater than 0.8 , the SCC has a good passing ability [35].

The V-Funnel test, that was used to check the Flowability of self-compacting concrete. The flow time of V-Funnel

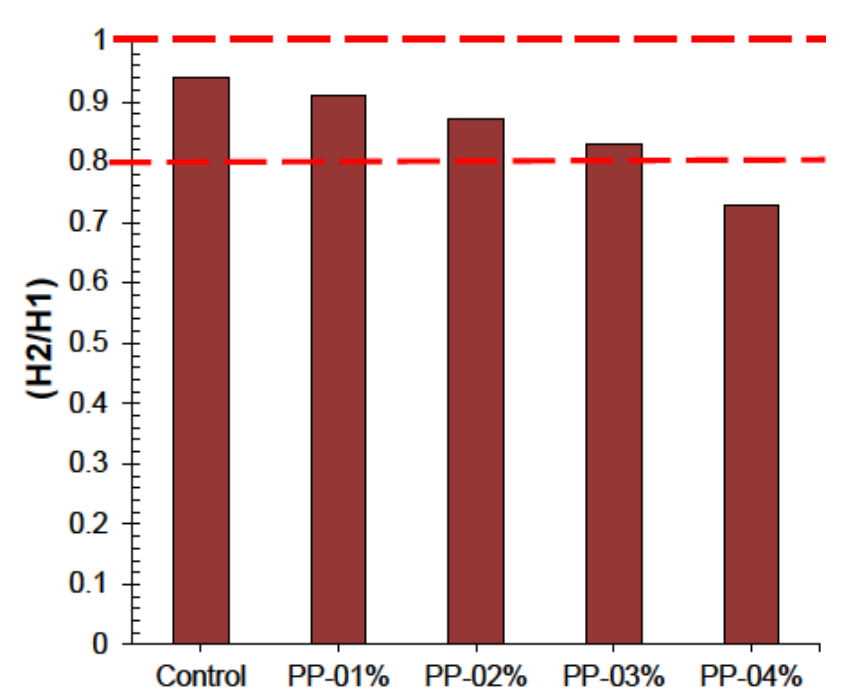

Figure 4: L-Box Test Results

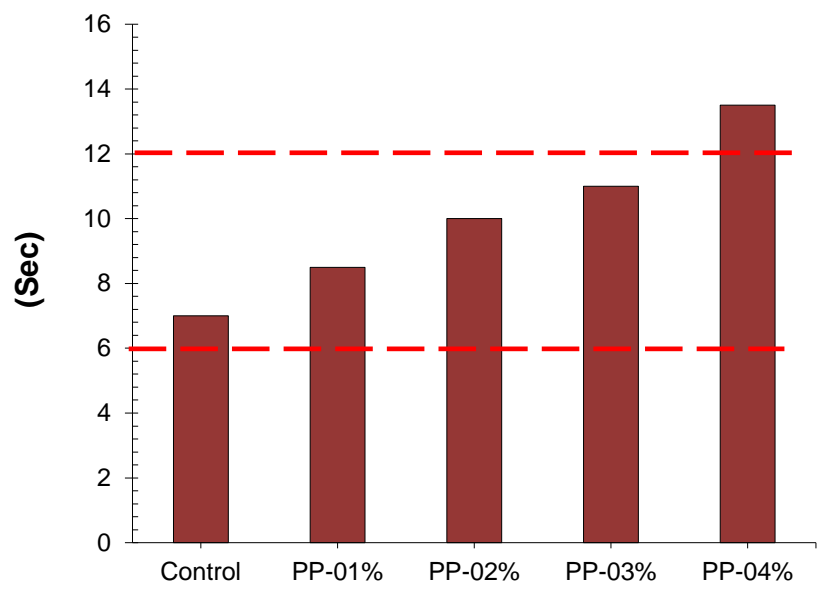

Figure 5: V Funnel Test Results

tests are used to find the filling ability of SCC. It measures the ease of flow of concrete. A shorter flow time indicates greater flowability. Similar to the slump flow test, the flowability of self-fibers compacting concrete decreased as the percentage of fiber increased. Maximum flowability was obtained when the substitution was $0 \%$ while minimum flowability was obtained at $2.0 \%$ substitution of PP. However flow time is between $6 \mathrm{sec}$ to $12 \mathrm{sec}$ for mix (PP-0\%, PP$1.0 \%$, PP-2.0\%, and PP-3.0\%) have acceptable range given by technical specification for SCC as shown in Figure 5. However, at a higher dosage of PP- $4.0 \%$ have flow time $13 \mathrm{sec}$ which is out of the range given by technical specification for SCC.

\subsubsection{Mechanical Properties}

\subsubsection{Compressive Strength}

Compressive strength is the measure of the greatest compressive loading concrete can withstand. The compressive strength test is performed under the standard procedure of ASTM as ASTM C39/C39M [31] for cylindrical specimens having standard dimensions as $150 \mathrm{~mm}$ diameter and $300 \mathrm{~mm}$ length.

Based on experimental test outcomes compressive strength increased as the percentage of SFs raised to 2.0 percent and then decreased as displayed in Figure 6. It has been reported that the compressive strength increased up to 2.0 percent addition of PP [36]. After 28 days of curing, the highest compressive strength was obtained at 2.0 percent dosage of PP as compared to blank or reference concrete. However, beyond the 2.0 percent dosage, the strength was reduced. The positive effect on compressive strength is due to the confinement of the fiber reinforcement on the specimen. Compression produces an expansion laterally, and with 
it, tension and shear. The tension and shear are resisted by the fibers. Therefore, compression is increased. When the percent of fibers is high this confinement can reduce transversal deformation of the specimen and increase its compressive strength. When increasing the PP percent especially of higher dosage the process of compaction will be difficult and then the compressive strength will be reduced. Adding up to 1.5 percent of fibers by volume raises the compressive strength from 0 percent to 15 percent [37]. fibers at 1.0 percent by volume causes a considerable improvement in early as well as long term compressive strength of concrete. The maximum enhancement in 28-days strength was recognized to be 29.15 percent [24]. For this reason, there is an optimum limit for the usage of PP. Test observation of the optimum dosage of PP which produces better strength is 2.0 percent steel fiber.

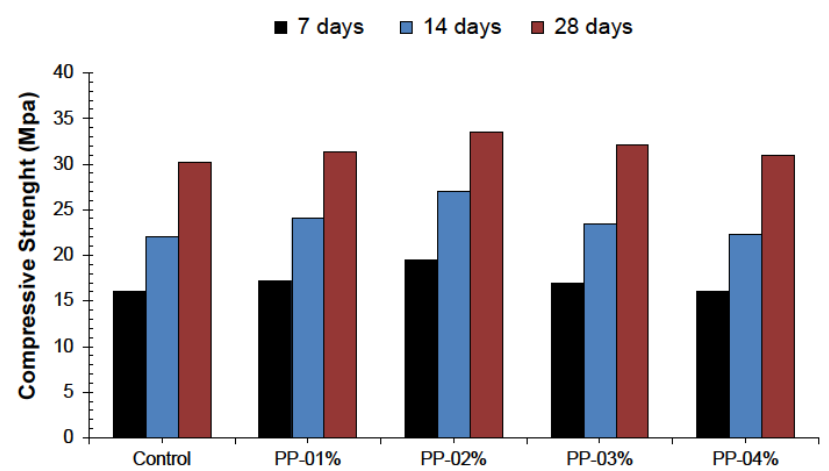

Figure 6: Compressive Strength Results

A relative analysis of compressive strength is also illustrated in Figure 7. Compressive strength of the control mix (Mix 6) at 28 days was taken as the reference. It can be observed from Figure 4, that overall, compressive strength increased increments with different dosages of PP is similar at deferent days of curing (7,14 and 28 days). At 28 days of curing, the compressive strength of concrete with 1.0 percent and 4.0 percent PP almost equal to the compressive strength of the reference mix, and a notable increase was observed for 2.0-3.0 percent of PP. At 14 days of curing, compressive strength almost 25 to 30 percent lower than the reference mixes up to 1.0 percent, 3.0 percent, and 4.0 percent of PP. Whereas 2.0 percent of PP compressive strength is $10 \%$ lower than the reference mix. At 7 days, compressive strength is almost 45 to $50 \%$ lower than the reference mix in a similar manner of 14 and 28 days. However, at a 2.0 percent substitution rate of PP, compressive strength was just 35 percent lower than from the blank/reference mix. It can be concluded that propylene fibers have a strong potential to enhance the compressive strength of SCC.

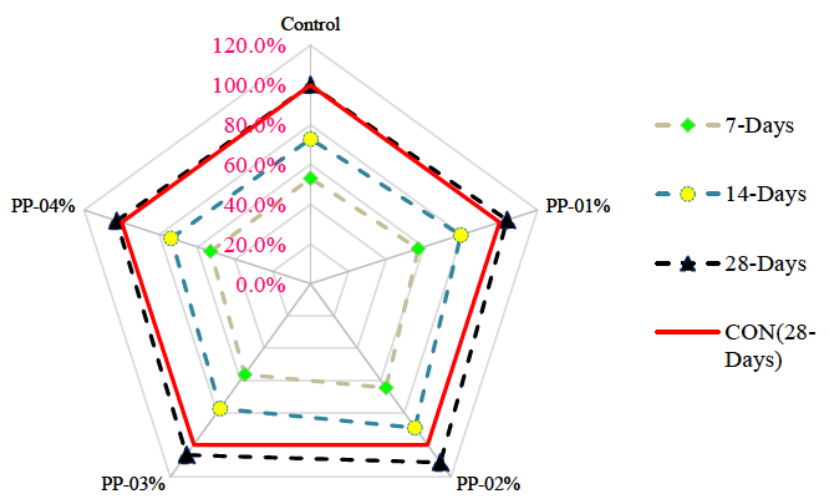

Figure 7: A relative compressive Strength Results

\subsubsection{Split Tensile Strength}

Tensile strength for concrete samples is called the tensile stresses generated due to applying the compressive load at which the concrete sample may fail. According to ASTM C496-71 (32), a split cylinder test was carried out on cylindrical specimens of $150 \mathrm{~mm}$ diameter and $300 \mathrm{~mm}$ height at the ages of 7, 14, and 28 days curing.

Based on experimental test results, similar to compressive strength split tensile strength was also increased as the percentage of SFs raised to 2.0 percent and then diminished as displayed in Figure 8. After 28 days of curing, the highest split tensile strength was obtained at 2.0 percent dosage of PP as compared to blank or reference concrete. Adding of 2.0 percent by volume of fibers can enhance the tensile strength of concrete to almost 40 percent [22]. However, beyond the 2.0 percent dosage, the strength was reduced. Fibers are mixed in concrete to increase the flexibility of concrete by halting the onset of tension cracks or preventing the generation of cracks in such a manner that tensile strength of (SFRC) steel fiber reinforced concrete displays better conduct than normal concrete. Fibers behave as crack stoppers and not as cracks prevention. Fibers are known to enhance the tensile capacity of post-cracking behavior [38]. Fibers have shown more significant effects on flexural tensile strength at 0.5 to 2.0 percent volume fractions used in this study [39].

Comparison of predicted values with experimental tensile strength values using ACI-318.11 codes is displayed in Figure 9. Equations (1) can be used to predict values of split tensile strength from compressive strength. It is noticed that all empirical values locate well within the anticipated values using ACI-318.11 codes. Regression models between split tensile strength and experimental values of compressive strength are displayed in Figure 9. A strong correlation exists $(R 2>0.90)$ between both strengths.

$$
f_{s p}=0.53 \times \sqrt{f c}
$$




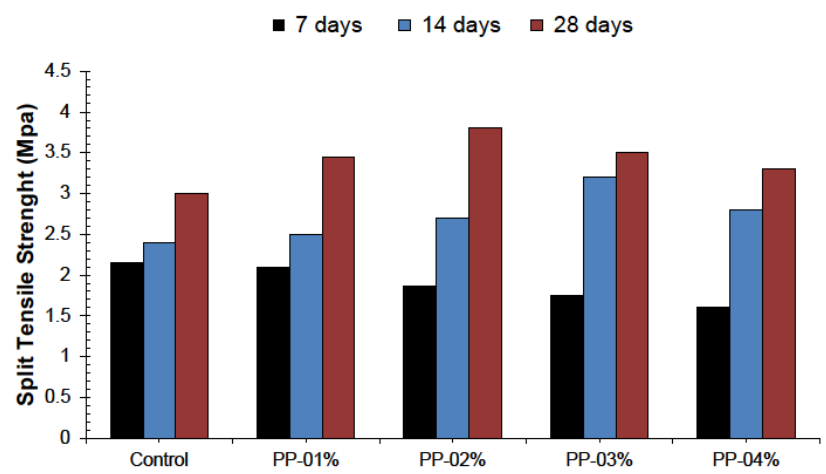

Figure 8: Split Tensile Strength Results

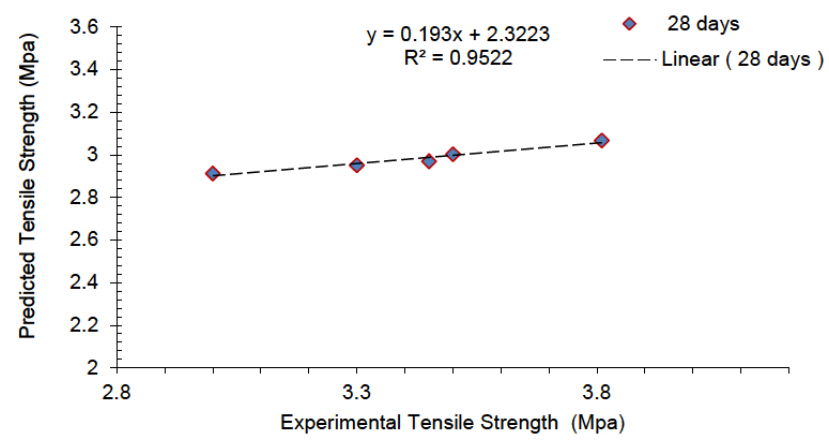

Figure 9: Co Relation Between Experimental and Predicted Split Tensile Strength

\section{Conclusion}

In this research, propylene fibers (PP) were added to concrete in proportion of $0 \%, 1.0 \%, 2.0 \%, 3.0 \%, 4.0 \%$ by weight of cement. Based on experiment tests, following conclusion has been made.

- The filling and passing ability of SCC considerably reduced with the incorporation of $\mathrm{PP}$. This is due to the increased surface area of fibers. In addition to the coarse aggregate, the mortar must also coat the fibers. More paste is required to a reduced fraction between coarse aggregate and fiber and which results in filling and passing ability of SSC decreased.

- The use of PP up to 2.0\%, provide SCC with acceptable fresh properties according to the technical specification for SCC. Therefore, it is recommended to use PP up to $2.0 \%$ (by weight of cement).

- All the PP reinforce concrete show greater strength (compressive and split tensile strength) than the blank mix, having maximum strength at $2.0 \%$ of PP (by weight of cement). However, beyond the $2 \%$ dosage, the strength was reduced. The positive effect on strength is due to the confinement of the fiber reinforcement on the specimen. Compression produces an expansion laterally, and with it, tension and shear. The tension and shear are resisted by the fibers. Therefore, the strength was increased. When increasing the steel fiber percent especially of higher dosage, the process of compaction will be difficult due to decreased workability which results in decreased strength.

- Finally, the present study concludes that propylene fibers (PP) are a good, available in abundance, local eco-material, low-cost, that can be used for the SCC production, in a perspective between economic and the environmental constraints.

Acknowledgement: This research project was supported by the deanship of scientific research at Prince Sattam Bin Abdulaziz University under the research project no. 2020/01/16810.

Conflict of Interests: The authors have no conflict of interest to declare.

\section{References}

[1] EFNARC S. Guidelines for self-compacting concrete. London, UK Assoc House. 2002;32:34.

[2] Okamura H. Self-compacting high-performance concrete. Concr Int. 1997;19(7):50-4.

[3] Ozawa K. High-performance concrete based on the durability design of concrete structures. In: Proc of the Second East AsiaPacific Conference on Structural Engineering and Construction, 1989. 1989.

[4] Ezeldin AS, Balaguru PN. Normal-and high-strength fiberreinforced concrete under compression. J Mater Civ Eng. 1992;4(4):415-29.

[5] Chang D-I, Chai W-K. Flexural fracture and fatigue behavior of steel-fiber-reinforced concrete structures. Nucl Eng Des. 1995;156(1-2):201-7.

[6] Banthia N. Report on the physical properties and durability of fiber-reinforced concrete. 2010;

[7] Behbahani HP, Nematollahi B, Farasatpour M. Steel fiber reinforced concrete: A review. 2011;

[8] Nielsen C V. Mechanical properties for green concrete. In: in Proceedings of XVIII Nordic Concrete Research Meeting, Helsingør, Denmark. 2002.

[9] Zheng Y, Cai Y, Zhang G, Fang H. Fatigue property of basalt fiber-modified asphalt mixture under complicated environment. J Wuhan Univ Technol Sci Ed. 2014;29(5):996-1004.

[10] Jaivignesh B, Sofi A. Study on mechanical properties of concrete using plastic waste as an aggregate. In: IOP Conference Series: Earth and Environmental Science. IOP Publishing; 2017. p. 12016. 
[11] Fan FL, Xu JY, Bai EL, He Q. Experimental study on impactmechanics properties of basalt fibre reinforced concrete. In: Advanced Materials Research. Trans Tech Publ; 2011. p. 1910-4.

[12] Akca AH, Özyurt N. Effects of re-curing on residual mechanical properties of concrete after high temperature exposure. Constr Build Mater. 2018;159:540-52.

[13] Bindiganavalie V, Banthia N. Some S tudies on the Impact Response of Fibre Reinforced Concrete. Indian Concr Inst J. 2002;23-8.

[14] Afroughsabet V, Biolzi L, Ozbakkaloglu T. High-performance fiberreinforced concrete: a review. J Mater Sci. 2016;51(14):6517-51.

[15] Wang Y, Wu HC, Li VC. Concrete reinforcement with recycled fibers. J Mater Civ Eng. 2000;12(4):314-9.

[16] Hughes BP, Fattuhi NI. The workability of steel-fibre-reinforced concrete. Mag Concr Res. 1976;28(96):157-61.

[17] Mehta PK, Monteiro PJM. Concrete microstructure, properties and materials. 2017.

[18] Muthupriya P, Manjunath N V, Keerdhana B. Strength study on fiber reinforced self-compacting concrete with fly ash and GGBFS. Int J Adv Struct Geotech Eng. 2014;3(2):75-9.

[19] Khaloo AR, Kim N. Influence of concrete and fiber characteristics on behavior of steel fiber reinforced concrete under direct shear. Mater J. 1997;94(6):592-601.

[20] Ou Y-C, Tsai M-S, Liu K-Y, Chang K-C. Compressive behavior of steel-fiber-reinforced concrete with a high reinforcing index. J Mater Civ Eng. 2012;24(2):207-15.

[21] Vairagade VS, Kene KS. Introduction to steel fiber reinforced concrete on engineering performance of concrete. Int J Sci Technol Res. 2012;1(4):141.

[22] Williamson GR. The effect of steel fibers on the compressive strength of concrete. Spec Publ. 1974;444:195-208.

[23] Murthy Dakshina NR. Splitting tensile strength of high volume fly ash concretes with and without steel fibers in different grades. In: International conference recent advance on concrete and construction technology. 2005.

[24] Usman M, Farooq SH, Umair M, Hanif A. Axial compressive behavior of confined steel fiber reinforced high strength concrete. Constr Build Mater. 2020;230:117043.

[25] Mohod M V. Performance of steel fiber reinforced concrete. Int J Eng Sci. 2012;1(12):1-4.
[26] Johnston CD. Measures of the workability of steel fiber reinforced concrete and their precision. Cem Concr aggregates. 1984;6(2):74-83.

[27] Balaguru P, Ramakrishnan V. Comparison of slump cone and VB tests as measures of workability for fiber-reinforced and plain concrete. Cem Concr aggregates. 1987;9(1):3-11.

[28] Cement AP. ASTM C150 of the following type: 1. Concr which will be contact with Sew Type II, Moderate Sulfate Resist. 2.

[29] EN TS. 934-2 "Admixtures For Concrete, Mortar and Grout-Part 2: Concrete Admixtures; Definitions, Requirements, Conformity, Marking and Labelling." Br Stand Inst. 2009;

[30] High-Range W-RA, Admixture R. ASTM C 494/C 494M. Type F.

[31] C39/C39M A. Standard test method for compressive strength of cylindrical concrete specimens. Annu B ASTM Stand. 2003;

[32] Designation A. C496-71. Stand Method Test Split Tensile Strength Cylind Concr Specimens. 1976;

[33] Specimen CT. ASTM C 31; one set of four standard cylinders for each compressive-strength test, unless otherwise directed. Mold store Cylind Lab test specimens Except when field-cured test specimens are required.

[34] Hamzah AF, Ibrahim MHW, Jamaluddin N, Jaya RP, Arshad MF, Abidin NEZ. Fresh characteristic and mechanical compressive strength development of self-compacting concrete integrating coal bottom ash as partial fine aggregates replacement. Int J Mech Mechatronics Eng. 2015;15(4):61-7.

[35] Iqbal S, Ali A, Holschemacher K, Ribakov Y, Bier TA. Effect of fly ash on properties of self-compacting high strength lightweight concrete. Period Polytech Civ Eng. 2017;61(1):81-7.

[36] Kikuchi T, Shintani Y, Hirashima T, Kohno M. Mechanical properties of steel fiber reinforced concrete at high temperature. J Struct Constr Eng. 2020;85(767):169-76.

[37] Tadepalli PR, Mo YL, Hsu TTC. Mechanical properties of steel fibre concrete. Mag Concr Res. 2013;65(8):462-74.

[38] Lim JC, Ozbakkaloglu T. Confinement model for FRP-confined high-strength concrete. J Compos Constr. 2014;18(4):4013058.

[39] Deluce JR, Vecchio FJ. Cracking Behavior of Steel Fiber-Reinforced Concrete Members Containing Conventional Reinforcement. ACI Struct J. 2013;110(3). 